\title{
A VEGETATION STUDY OF CAPITOL REEF NATIONAL PARK
}

\author{
Kenneth D. Heil \\ Rich Fleming \\ San Juan College \\ Farmington, NM \\ J. Mark Porter \\ william H. Romme \\ Ft. Lewis College \\ Durango, $\mathrm{CO}$
}

\section{Objectives}

Capitol Reef National Park lies in a relatively unexplored region of southcentral Utah. The diversity in geology and the elevation gradient $(3,500-9,000$ feet) allows for diverse vegetation including endemic and rare taxa (Welsh and Chatterley, 1985). Previous floristic studies have been conducted in San Rafael Swell (Harris, 1980) and the Henry Mountains (Neese, 1981); however, aside from classification of coniferous habitat types (Youngblood and Mauk, 1985), no community studies have been done in this region.

This was the first year of a two year investigation of the plant communities, flora, threatened, endangered/sensitive taxa distribution and the effects of grazing in Capitol Reef National Park. Our specific objectives for the project are:

1. To classify and map plant communities in the park on U.S.G.S. quadrangle maps;

2. To complete an annotated list of vascular plant species identifying origin, form, duration, special status, flower color, general location, abundance, flowering dates, habitat, geology, special use information, elevation and effects of grazing;

3. To define the potential climax vegetation for each type of community and to make recommendations for maintaining that climax vegetation or appropriate seral stages, if those are necessary for maintaining populations of certain rare plants;

4. To identify and map locations (on U.S.G.S. quads) for all threatened, endangered, sensitive (rare) and exotic species;

5. To identify all immediate and potential threats to threatened, endangered, and sensitive species;

6. To collect, press, mount and label vascular plant specimens for the park herbarium; 
7. To photograph all threatened-endangered plants and com munity types; and

8. To evaluate the grazing impact on waterpockets using Cottonwood, Willow and Mia-hey-yun Tanks as examples.

This study will provide baseline ecological data for Capitol Reef National Park. Benefits from this project will include maps of the community types and distributions for rare taxa, additional plants for the herbarium, annotated plant list and some information on the effects of grazing.

\section{Methodology}

The classification scheme that is currently being developed is designed to use for management purposes. It will (1) provide a general description of major natural associations of plant species in the area and (2) describe the kinds of habitats and communities within which rare plant species are most likely to be found.

We have collected releve data (subjective estimates of the abundance of each species-Mueller-Dombois, and Ellenberg, 1974) in 228 stands (50M x 50M) representing a major portion of the range of elevation, topographic position, geological substrate and disturbance history throughout the park. This type of data is collected quickly and easily while surveying transects for plant collections and it is semiquanitative. The resulting releves are being subjected to multivariant analysis in the form of a species by sample matrix using three Cornell University community ecology programs: "Ordiflex" (Reciprocal averaging), "Decorana" (Detrended Corrispondance Analysis Ordination) and Twinspan (Gauch, 1983). A VAX Digital Computer at Fort Lewis College, Durango, Colorado is being used for this analysis.

Because the number of discrete vegetative groups will passibly exceed 35-40, based on our field season observations, it may be necessary to combine some types into complexes for the preliminary map. Statistically this will be done with hierarchical clustering (Twinspan). The reason for the clustering is the impractibility of a 35-40 com munity type system for management considerations. The classification will then be used to make the preliminary com munity maps on $71 / 2$ minute orthoquads.

The transects have been run primarily in an east/west orientation, which has proven to maximize the number of geologic formations intersected by the transect. The far north portions of the park are best covered by transects which nun northeast/southwest. The use of partial transects is advantageous in regions where topography (steep relief) makes completions of a transect across the park impossible.

Along each transect, plants have been collected and within areas of uniform vegetation releve stands have been done. In addition to the types of data collected during the previous season and the 1987 field season, the community type according to the preliminary map will be recorded. This will allow an 
assessment of the accuracy of the preliminary map.

Known sites of threatened-endangered and sensitive plant species have been visited during respective blooming periods in order to photograph and map the park's rare plant species. Their habitat was evaluated so that similar habitat could be recognized during the transect studies. When threatened-endangered and sensitive plants were encountered notes were taken regarding plant com munity, number of plants and size of population.

\section{Results}

After the first year's field season, we are determining and mapping a preliminary com munity classification. Threatened and endangered plants are also being mapped. An annotated list of all of the plants found in the park is being compiled. Voucher specimens of plants have been identified, mounted, labeled and will be given to Capital Reef National Park Herbarium. Dr. Stan Welsh has assisted in taxonomic evaluation of specimens. Nomenclature has followed Cronquist, et. al. (1972, 1977, 1984) when possible. Other texts being used include Welsh (1986); McDougal (1973). Generic revisions have been used when applicable.

During the 1986 field season we located 19 sensitive plant taxa in the park, four of which have federal protection. The investigators have found 170 previously unrecorded taxa in the park bringing the total to approximately 770 plant species in Capitol Reef National Park.

We plan to complete our sampling during the 1987 field season, subject to continued funding. This will provide us with a sample from the full range of variation in elevation, topography, and geologic substrate in Capitol Reef National Park. Based on this complete data set, we will then develop our final classification, maps, and report during the winter of 1987-88.

\section{Conclusions}

No conclusions are possible at this time.

References Cited and Bibliography

Cronquist, A., A. Holmgren, N. Holmgren and J. Reveal 1972. Intermountain Flora Vol, 1, Vascular Cryptograms and Gymnosperms. New York Botanical Garden, Hofner Publishing, New York.

Cronquist, A., A. Holmgren, N. Holmgren and P. Holmgren. 1977. Intermountain Flora Vol. 6, The Monocotyledons. New York Botanical Garden, Columbia University Press, New York.

Cronquist, A., A. Holmgren, N. Holmgren and P. Holmgren. 1984. Intermountain Flora Vol, 4, Asteridae (except Asteraceae). New York Botanical Garden,

$$
-39-
$$


Bronx, New York.

Gauch, H. G. 1981. Multivariate Analysis in Community Ecology. Cambridge University Press, New York.

Harris, J. G. 1980. A vascular flora of the San Rafael Swell, Utah. Great Basin Naturalist. 43:79-87.

Mueller-Dombois, D. and H. Ellenberg. 1974. Aims and Methods of Vegetation Ecology. Wiley, New York.

Neese, E. J. 1981. A vascular flora of the Henry Mountains, Utah. Unpublished Ph.D, dissertation, Brigham Young University, Provo, Utah.

Welsh, S. I. and L. M. Chatterley. 1985. Utah's rare plants revisited. Great Basin Naturalist. 45:173-236.

Welsh, S. L., N. D. Atwood, L. C. Higgins, and S. Goodrich. 1986. A Utah Flora, Great Basin Naturalist Memoir 9, Provo, Utah. 